\title{
ESSENTIAL AND TOXIC ELEMENT BIOACCUMULATIONS IN FISHES OF GALA AND SIĞIRCI LAKES (MERIÇ RIVER DELTA, TURKEY)
}

\author{
C. TOKATLI* \\ Department of Laboratory Technology, İpsala Vocational School, Trakya University, Bayrambey Quarter, \\ Enez Street, No.140, 22400, İpsala / Edirne. Turkey
}

(Received: 11 February 2018; accepted: 25 April 2018)

\begin{abstract}
Meriç River Delta is located in the Thrace Region of Turkey, and it is one of the most important wetlands worldwide. Gala and Sığırcı Lakes, which are known as significant lakes in Turkey in terms of especial biodiversity, are located in the Meriç River Delta and they are the main lentic factors of the system. The aim of this study was to evaluate the essential and toxic element bioaccumulation levels in fishes of Gala and Sığırcı Lakes from a statistical perspective by investigating a total of 25 macro- and micro-element bioaccumulations. One-Way ANOVA Test (OWAT) was applied to detected data in order to determine the statistical differences of element bioaccumulations among the fish species. Cluster analysis (CA) was also applied to detected data in order to classify the investigated elements in terms of bioaccumulation levels in fish tissues. According to the results of OWAT, although statistical differences were not recorded among the fish species in terms of essential element levels, significant statistical differences were recorded in terms of toxic element levels $(\mathrm{P}<0.05)$. According to the results of CA, 5 statistically significant clusters were formed, which were named as "Most intense elements", "Second most intense elements", "Moderate intense elements", "Second rarest elements", and "Rarest elements". It was also found that toxic element bioaccumulation rates in fishes of Gala Lake were significantly higher than in fishes of Siğırcı Lake $(\mathrm{P}<0.05)$.
\end{abstract}

Keywords: Gala and Sığırcı lakes, fishes, macro- and micro-elements, bio-statistics

Meriç Delta, which is formed on about 45,000 ha area at the mouth of Meriç River in Thrace Region of Turkey, is among the richest aquatic habitats not only of Turkey but the world especially in terms of bird existence. It is classified as an "A Class Wetland" according to the international criteria, which means that it can house more than 25000 waterfowls at the same time (ÇAMUR-ELIPEK et al., 2010). This internationally significant ecosystem is being exposed to an intensive pollution by means of agricultural, domestic, and industrial applications. Paddy agriculture conducted around the Meriç River (about $25 \%$ of total rice production of Turkey is being supplied from this basin) and industrial activities conducted around the Ergene River, which is known as one of the most polluted river ecosystems in Turkey, are considered the main contamination factors pressuring the system (ToKATLI, 2015; 2017).

Gala Lake (declared as "National Park" in 2005), which provides dwelling for many bird species migrating between Europe and Africa, and Sığırcı Lake, which is especially important for local fishery activities, are significant areas of Meriç Delta. These lakes are also being used for irrigation of paddy fields, and then drainage waters of agricultural lands are being discharged again into them through drainage canals (GüHER et al., 2011).

The aim of this study was to determine some essential and toxic element bioaccumulation levels in muscle, gill, and liver tissues of Carassius gibelio (Bloch, 1782), Carassius

\footnotetext{
* To whom correspondence should be addressed. Phone: +90 28461613 48/128; fax:+90 28461635 34; e-mails: cemtokatli@trakya.edu.tr; cemtokatli@gmail. com
} 
carassius (Linnaeus, 1758), Scardinius erythrophthalmus (Linnaeus, 1758), Cyprinus carpio Linnaeus, 1758, Sander lucioperca (Linnaeus, 1758), and Perca fluviatilis Linnaeus, 1758 living in Gala and Sığırcı Lakes, which have great importance especially in the diet of the local people.

\section{Materials and methods}

\subsection{Study area and collection of samples}

The map of Lower Basin of the Meriç River including Gala and Sığırcı Lakes that was drawn using the ArcGIS program is given in Figure 1. The fish samples were caught by fishermen's nets from Gala and Siğırcı Lakes at the summer season of 2016. The muscle, liver, and gill tissues of each species were dissected in the laboratory. The metric characteristics of investigated fish species are given in Table 1.

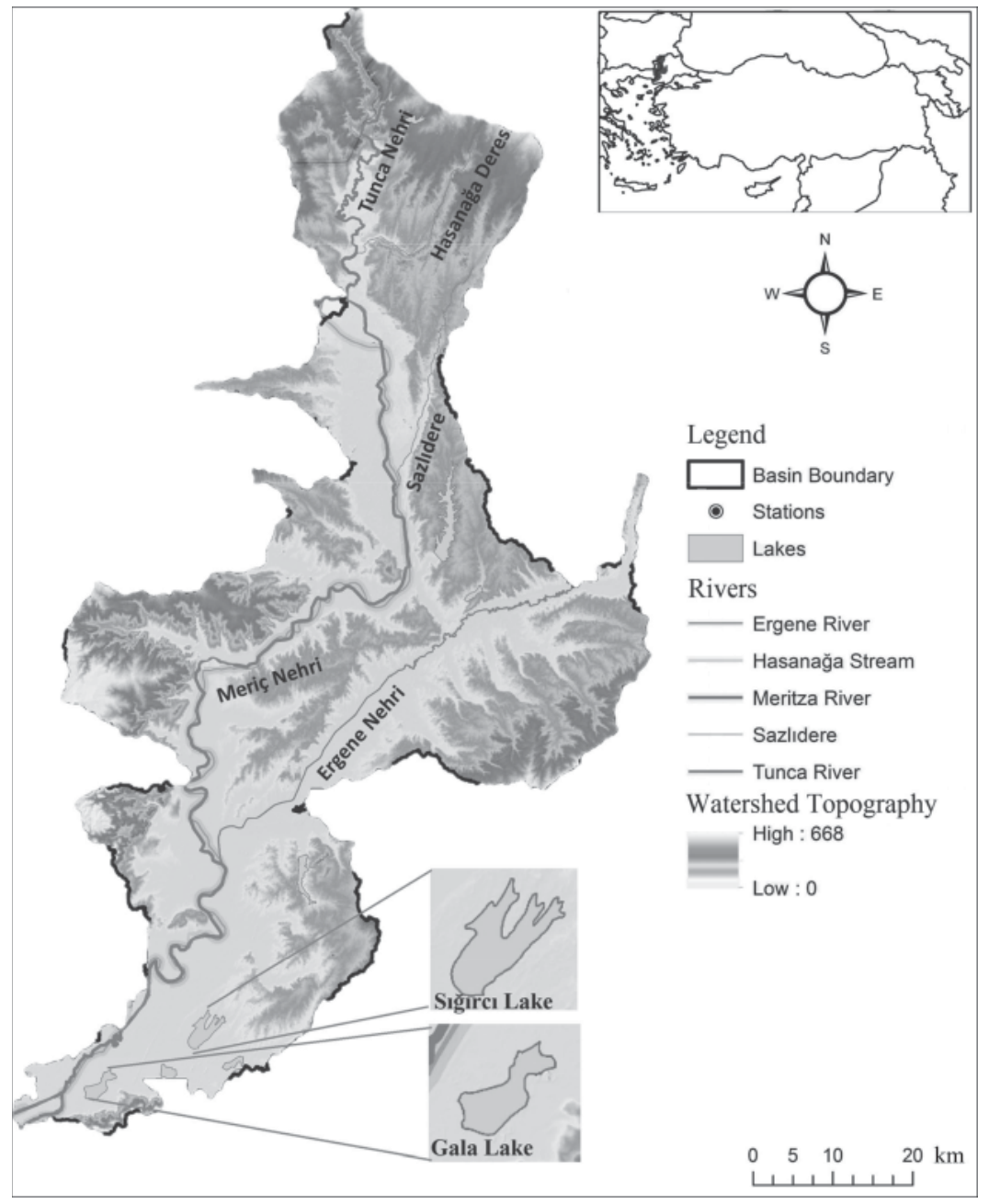

Fig. 1. Meriç River Basin and investigated lakes 
Table 1. Metric characteristics of fishes caught from Gala and Sığırcı Lakes

\begin{tabular}{llcccc}
\hline Locality & Fish species & \multirow{2}{*}{$\begin{array}{l}\text { Weight } \\
(\mathrm{g} \pm \mathrm{SD})\end{array}$} & & \multicolumn{3}{c}{ Length $(\mathrm{mm} \pm \mathrm{SD})$} \\
\cline { 4 - 6 } & & & Standard & Fork & Total \\
\hline Gala Lake & C. gibelio $(\mathrm{n}=4)$ & $552.5 \pm 9.8$ & $243.7 \pm 14.2$ & $270.2 \pm 15$ & $284.7 \pm 18.1$ \\
& C. carassius $(\mathrm{n}=5)$ & $1166 \pm 105$ & $315 \pm 16.9$ & $342.2 \pm 15.6$ & $385.8 \pm 11.1$ \\
Siğırc1 Lake & S. erythroph. $(\mathrm{n}=5)$ & $261.6 \pm 5.2$ & $241.4 \pm 12.1$ & $264.8 \pm 12.6$ & $287 \pm 13.5$ \\
& C. carpio $(\mathrm{n}=2)$ & $1115 \pm 49.4$ & $306.5 \pm 9.1$ & $332 \pm 11.3$ & $369.5 \pm 7.7$ \\
& S. lucioperca $(\mathrm{n}=1)$ & $430 \pm 0$ & $333 \pm 0$ & $362 \pm 0$ & $375 \pm 0$ \\
& P. fluviatilis $(\mathrm{n}=3)$ & $189.3 \pm 14$ & $198.3 \pm 22.5$ & $216.6 \pm 16$ & $228.3 \pm 20.2$ \\
\hline
\end{tabular}

\subsection{Chemical analysis}

Fish samples were dried for $24 \mathrm{~h}$ at $105{ }^{\circ} \mathrm{C}$ and placed ( $0.50 \mathrm{~g}$ of each sample) in Pyrex reactors of a CEM Mars Xpress 5 microwave digestion unit. $\mathrm{HClO}_{4}: \mathrm{HNO}_{3}$ acids of 1:3 proportions were added to the reactors. Samples were mineralized at $200^{\circ} \mathrm{C}$ for thirty minutes. Afterwards, the samples were filtered in a way to make their volumes up to $100 \mathrm{ml}$ with ultrapure distilled water.

The element levels in fish tissues were determined by using the 'Agilent 7700xx' branded Inductively Coupled Plasma - Mass Spectrometer (ICP-MS) device in Trakya University, Technology Research, Development and Application Center (TÜTAGEM). The centre has an international accreditation certificate within the scope of TS EN ISO/IEC 17025 (2017) issued by TÜRKAK (representative of the World Accreditation Authority in Turkey). The element analyses were recorded as means of triplicate measurements (ASTM, 1985; EPA, 1998; 2001).

\subsection{Statistical analysis}

Cluster analysis according to the Bray Curtis was applied to the results by using the PAST package program. One-Way ANOVA Test was applied to the results by using the SPSS 17 package program.

\section{Results and discussion}

\subsection{Cluster analysis (CA)}

Cluster analysis (CA) is an important group of multivariate statistical techniques, and the primary purpose of CA is classifying the objects based on their characteristics (SHRESTHA \& KazAma, 2007). In this study, CA was used to determine the similar groups among the investigated essential and toxic elements according to bioaccumulation levels in fish tissues. The data of CA was calculated by using macro- and micro-element bioaccumulation levels in muscle, gill, and liver tissues of investigated 5 fish species obtained from Meriç River Delta are given in Figure $2(\mathrm{n}=18)$.

According to the results of $\mathrm{CA}$, a total of 5 clusters were determined. 1. cluster was formed by the elements of $\mathrm{Na}, \mathrm{Ca}, \mathrm{Mg}$, and $\mathrm{K}$ (most intense elements); 2. cluster was formed 
by the elements of $\mathrm{B}, \mathrm{Fe}, \mathrm{Al}, \mathrm{Zn}$, and $\mathrm{Sr}$ (second most intense elements); 3. cluster was formed by the elements of $\mathrm{Mn}, \mathrm{Ba}$, and $\mathrm{Li}$ (moderate intense elements); 4. cluster was formed by the elements of $\mathrm{V}, \mathrm{Cr}, \mathrm{As}, \mathrm{Ni}, \mathrm{Se}, \mathrm{Ag}, \mathrm{Pb}, \mathrm{Cu}$, and $\mathrm{Ga}$ (second rarest elements); 5. cluster was formed by the elements of $\mathrm{Co}, \mathrm{Cd}, \mathrm{Sb}$, and $\mathrm{Tl}$ (rarest elements).

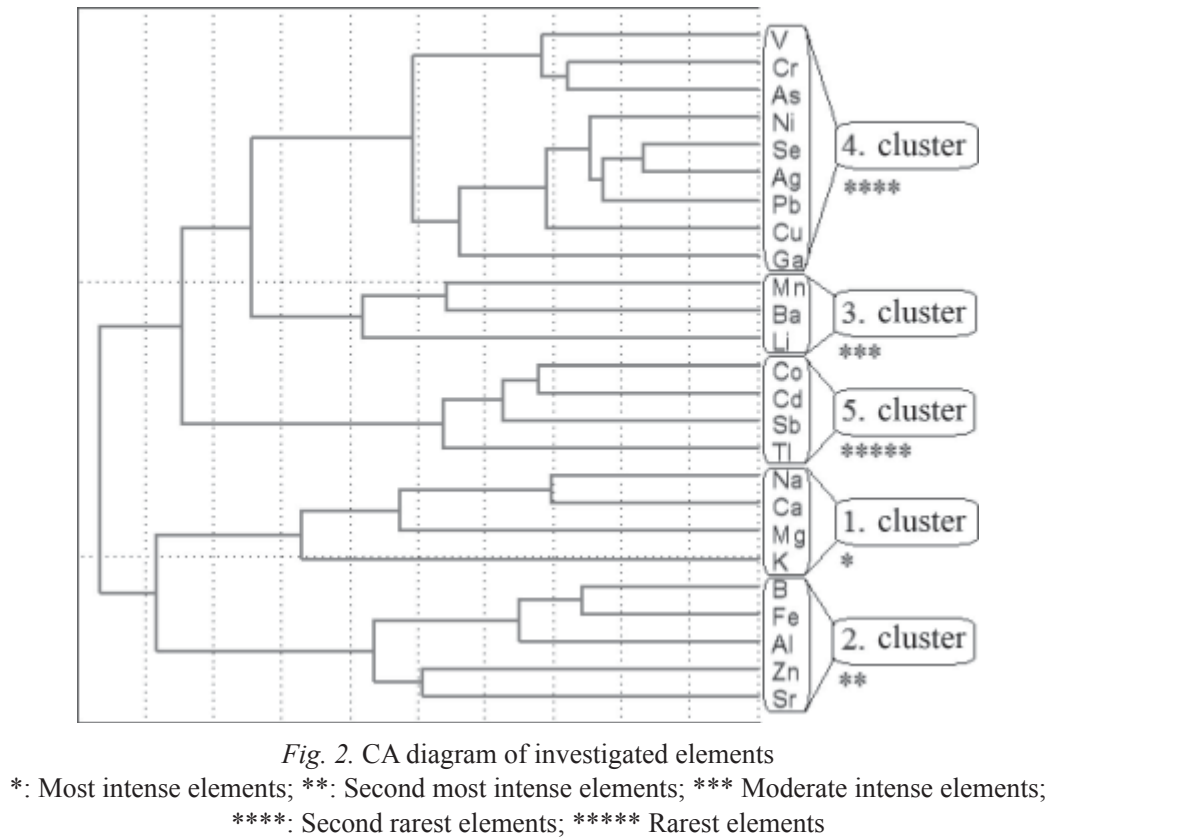

****: Second rarest elements; $* * * * *$ Rarest elements

In a study performed in the same basin, CA was used in order to classify the element accumulation in sediment samples of Meriç River Basin. According to the results of this study, 5 statistically significant clusters were formed, and similar to the present study, they were named as "most intense elements", "second most intense elements", "moderate intense elements", "second rarest elements", and "rarest elements" (ToKatLi \& BaŞTATLi, 2016).

\subsection{One-Way ANOVA Test (OWAT)}

Element bioaccumulation levels in muscle, gill, and liver tissues of 5 fish species caught from Meriç River Delta and the results of One-Way ANOVA Test (OWAT) are given in Figure 3. Macro- and micro-element concentration rates in fishes of Gala and Sı̆̆ırcı Lakes classified by using the results of CA are given in Figure 4.

According to the results of OWAT, statistical differences were not detected among the investigated fish species in terms of essential element levels (Fig. 3, subfig 1, 2, 3), but significant statistical differences were detected in terms of toxic element levels in general $(\mathrm{P}<0.05)$. Bioaccumulation levels of second rarest elements in C. gibelio and C. carassius are significantly higher than detected in S. lucioperca (Fig. 3, subfig. 4), and bioaccumulation levels of rarest elements in C. gibelio are significantly higher than detected in C. carpio and S. lucioperca (Fig. 3, subfig. 5). 

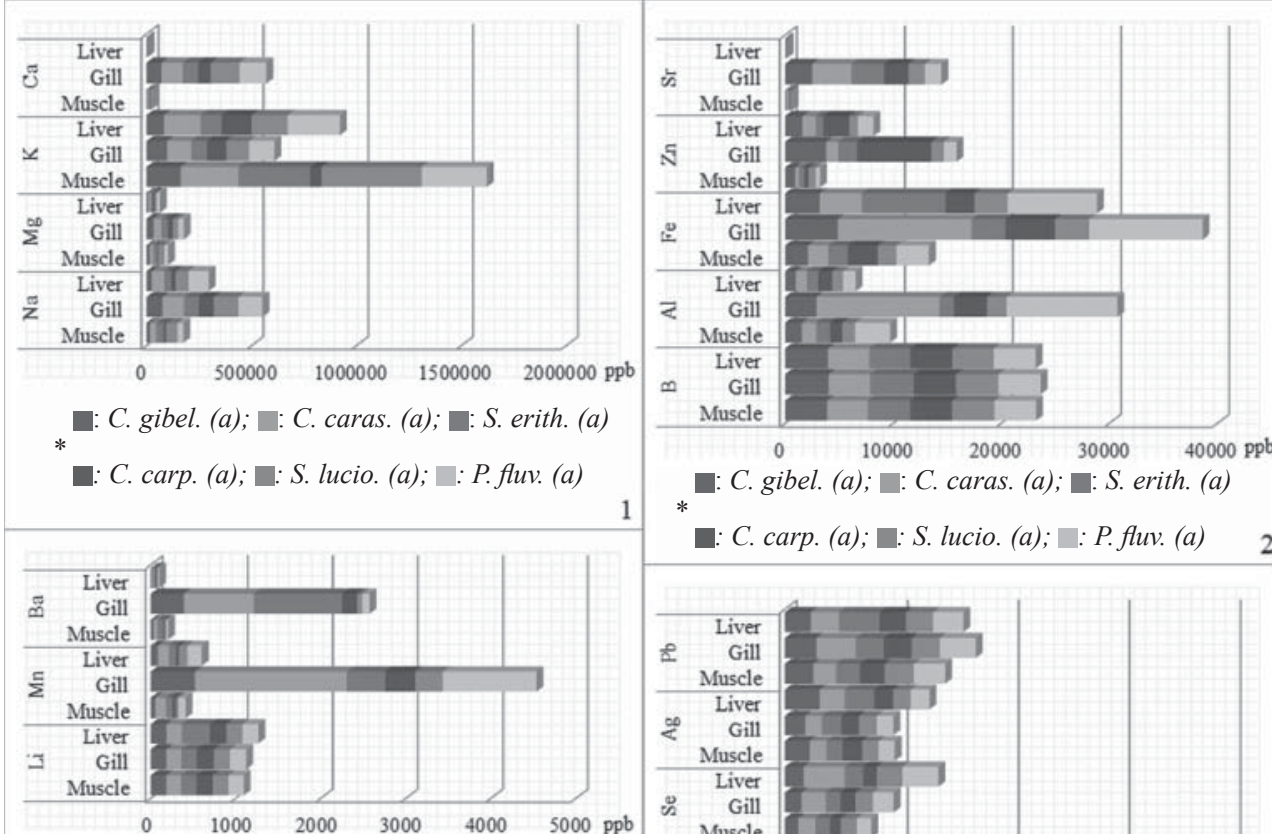

ㅁ: C. gibel. (a); 므: C. caras. (a); ㅁ: S. erith. (a)$$
*
$$

: C. carp. (a); ㅁ: S. lucio. (a); ㅁ: P. fluv. (a)

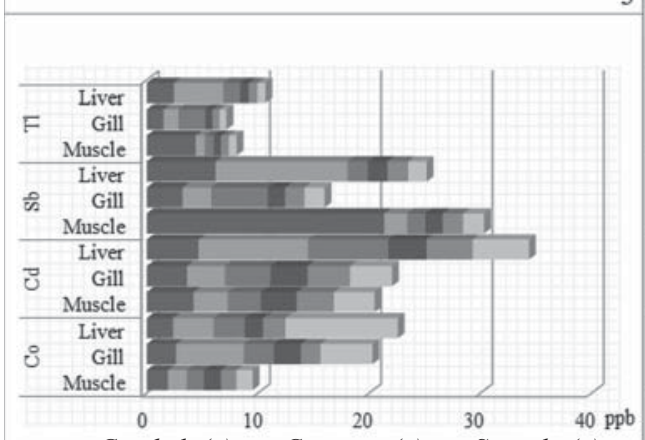

*

: C. gibel. (a); : C. caras. (a); ㅁ: S. erith. (a)

ㅁ. C. carp. (a); ㅁ: S. lucio. (a); : P. fluv. (a)

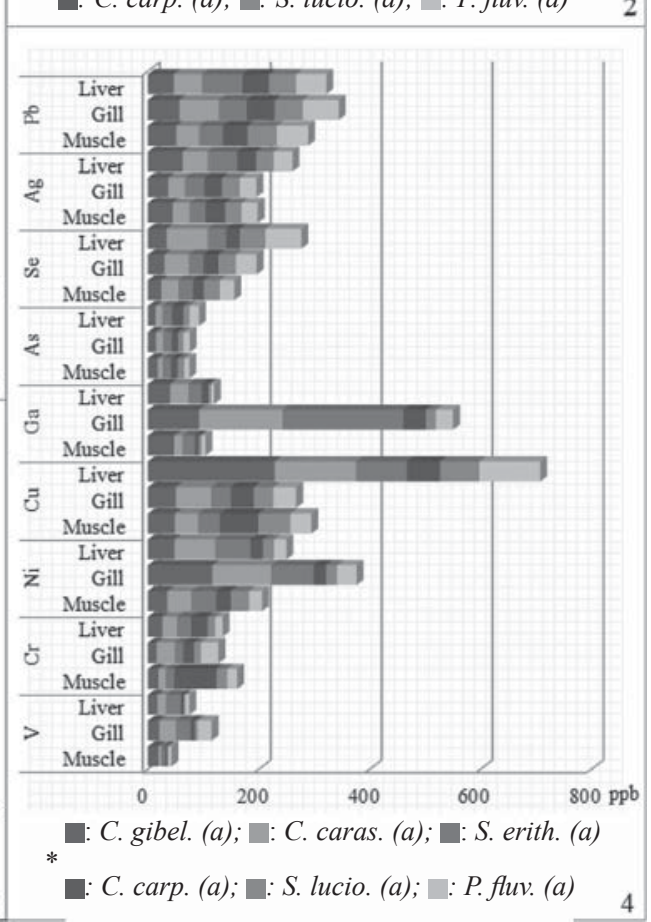

Fig. 3. Results of OWAT and element bioaccumulations in Meriç River Delta fishes

3.1: $\mathrm{Na}, \mathrm{Mg}, \mathrm{K}$, and Ca bioaccumulations; 3.2: B, Al, Fe, Zn, and $\mathrm{Sr}$ bioaccumulations;

3.3: $\mathrm{Li}, \mathrm{Mn}$, and $\mathrm{Ba}$ bioaccumulations; 3.4: $\mathrm{V}, \mathrm{Cr}, \mathrm{Ni}, \mathrm{Cu}, \mathrm{Ca}, \mathrm{As}, \mathrm{Se}, \mathrm{Ag}$, and $\mathrm{Pb}$ bioaccumulations; 3.5: $\mathrm{Co}, \mathrm{Cd}, \mathrm{Sb}$, and $\mathrm{Tl}$ bioaccumulations

*: The fish species marked with different letters in brackets are statistically different $(\mathrm{P}<0.05)$

As a result of OWAT, statistical differences were also determined between the investigated lakes. Toxic element concentration rates (rarest and second rarest elements) recorded in muscle, gill, and liver tissues of Gala Lake fishes (C. gibelio and C. carassius) are significantly higher than recorded in muscle, gill, and liver tissues of Sığırcı Lake ( $S$. 
erythrophthalmus, C. carpio, S. lucioperca, and P. fluviatilis) in general $(\mathrm{P}<0.05)$ (Fig. 4, subfigs 4,5$)$.

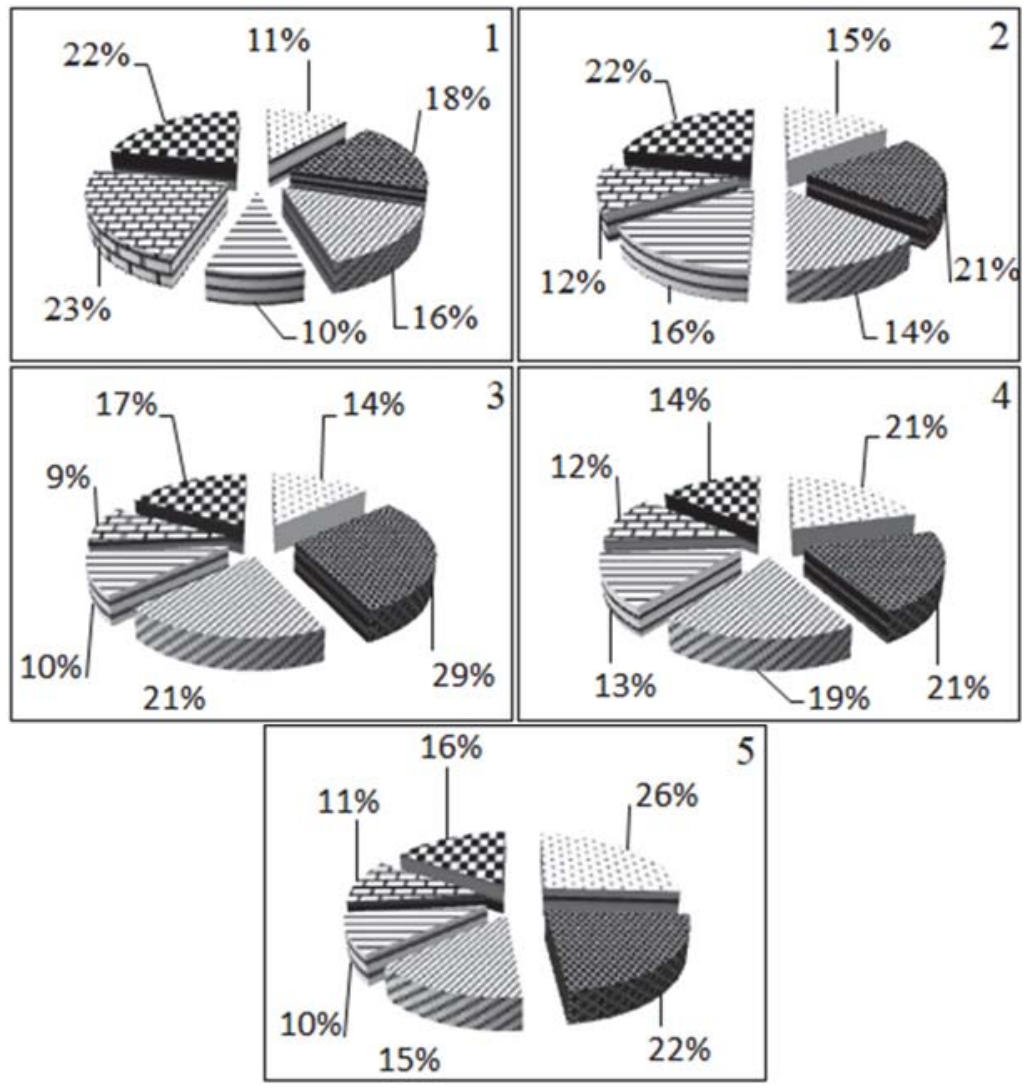

Fig. 4. Element bioaccumulation rates in Meriç River Delta fishes C. gibel. 즜 $C$. caras. " $S$. eryth. $\equiv C$. carp. 포 $S$. hucio. $\times P$. fluv,

4.1: Most intense elements; 4.2: Second most intense elements; 4.3: Moderate intense elements; 4.4: Second rarest elements; 4.5: Rarest elements

The only fish tissue that can be eaten by humans is muscle. Although muscle tissue has an inactive structure of toxic element binding, the toxicants bioaccumulated in muscle tissues of fishes can easily pass to people. Therefore, many organizations such as TGK (Turkish Food Codex), FAO (Food and Agricultural Organization), WHO (World Health Organization), and EPA (Environmental Protection Agency) specified the limit values of toxic elements in muscle tissues of fishes. As a result of this study, although highest bioaccumulations of $\mathrm{K}, \mathrm{Cr}$, and $\mathrm{Sb}$ were recorded in muscle tissues in general, toxic element bioaccumulation levels in muscle tissues of investigated fish species were not exceeded the limit values in terms of $\mathrm{Zn}$ (50 ppm, TGK (2008)), Cr (0.15 ppm, FAO (1983)), Ni (0.4 ppm, FAO (1983)), Cu (20 ppm, TGK (2008)), As (1 ppm, TGK (2008)), Pb (0.2 ppm, TGK (2008)), and Cd (0.05 ppm, TGK (2008)). In a study performed in Lover Basin of Meriç River, some macro- and micro-element contents in fish tissues were investigated, and it was reported that $\mathrm{Cd}, \mathrm{Pb}, \mathrm{Ni}$, and $\mathrm{Cr}$ 
bioaccumulation levels detected in muscle tissues of fishes were found to be significantly higher than the limits for human consumption (ToKATLI et al., 2016a). In another study performed in the Altınyazı Reservoir, located in the Meriç River Basin, some toxic metal concentrations in fish tissues were investigated. According to the results of this study, although the values of $\mathrm{Cr}, \mathrm{Zn}$, and $\mathrm{Cu}$ were recorded within the acceptable limits similar to the present study, the values of $\mathrm{Cd}$ and $\mathrm{Pb}$ were recorded above the acceptable limit values (ÇETIN et al., 2016).

Gill tissues are the gas exchange organ of the fishes, and they are clearly in contact with water. During this exchange, primer and secondary gill filaments are in contact with toxicants located in water. Therefore, toxic element concentrations in water and gill tissues show a close relationship. This situation makes gill tissue a significant and commonly used organ in toxicological studies (Altindă̆ \& Yı̈̆ıT, 2005; KöSE et al., 2015). In the present study, highest bioaccumulations of $\mathrm{Ca}, \mathrm{Mg}, \mathrm{Na}, \mathrm{Sr}, \mathrm{Zn}, \mathrm{Fe}, \mathrm{Al}, \mathrm{B}, \mathrm{Ba}, \mathrm{Mn}, \mathrm{Pb}, \mathrm{Ga}, \mathrm{Ni}$, and $\mathrm{V}$ were recorded in gill tissues in general.

It is known that trace and toxic elements are accumulating in metabolically active tissues, especially when the fishes are exposed to them for a long time. The detoxification mechanisms of fishes are similar. Toxicants are primarily linked to the metallothionein protein and these metallothioneins form complexes with toxic element ions. Liver tissue is the detoxification organ of the fishes, and it contains many of these proteins. Therefore, liver tissue bioaccumulates toxicants significantly better than other tissues like gills and muscles (Lu et al., 2011; TOKATLI et al., 2016b). But it is also known that the species of fishes, different physiological structures, and exposures durations of toxicants may affect bioaccumulation of them in different organs at different levels (AL-WeHER, 2008; ÇıçEK et al., 2017). According to the results of this study, the highest bioaccumulations of $\mathrm{Ag}, \mathrm{Se}, \mathrm{As}, \mathrm{Cu}, \mathrm{Tl}, \mathrm{Cd}$, and $\mathrm{Co}$ were recorded in liver tissues in general, because of the high toxicity of these elements. The higher bioaccumulation in liver tissues of fishes may alter the levels of various biochemical parameters in this organ, and this may also cause significant liver damage and a primary impact on the health of fish (Di Giulio \& Hinton, 2008; Newman, 2015).

Trace and toxic elements occur naturally in earth's crust. Although the transition of them to the environment can occur in many ways including natural processes, the most important of these ways are human activities, mostly domestic, agricultural, and industrial applications (Di Giulio \& Hinton, 2008; Newman, 2015). Meriç River Delta is known as an "Agriculture Land", and about $25 \%$ of total rice production of Turkey is being supplied from this basin. Also, Ergene River, which is the main tributary of Meriç River, is one of the most significant river basins located in the Thrace Region of Turkey, and about 1000 industrial companies are located on its water catchment area (TOKATLI, 2015). Results of the present study and many researches conducted on biotic and abiotic factors of the system (ÖZKAN \& ÇAMUR-ELIPEK, 2006; ÖZKAN et al., 2010; GÜNGÖRDÜ et al., 2012; ToKATLI \& BAŞTATLI, 2016) reflect that this significant aquatic ecosystem and the fishes as the most important biotic components of the delta are under pressure from these intensive agricultural and industrial activities.

\section{Conclusions}

In this study, some essential and toxic element bioaccumulations in muscle, gill, and liver tissues of fishes living in Gala and Sığırcı Lakes (Meriç River Delta) were investigated, and statistical methods were used to evaluate the recieved data. 
Cluster analysis grouped 25 macro- and micro-elements into 5 clusters of similar bioaccumulation characteristics; "Most intense elements", "Second most intense elements", "Moderate intense elements", "Second rarest elements", and "Rarest elements".

Significant differences of element bioaccumulations in fishes living in Gala and Siğırcı Lakes were recorded by using One-Way ANOVA Test, and according to the data obtained, the toxic element contamination rates among the investigated fish species living in Meriç River Delta were as follows: C. gibelio $>C$. carassius $>P$. fluviatilis $>S$. erythrophthalmus $>S$. lucioperca $>C$. carpio in general. However, for now, it has been determined that the concentration of toxic elements in muscle tissues of investigated fishes do not exceed the limit values for human consumption.

The obtained data clearly reveal that agricultural runoff caused from especially paddy fields around the basin, municipal sewage water from settlement areas located in the basin, and the industrial discharges from Ergene River are the main risk factors for the biotic components of the Meriç River Basin. If such contamination persists, bioaccumulation of inorganic toxicants in tissues of fish species may reach the critical levels and may adversely affect the fish and human health in the near future.

This research was financially supported by the Trakya University Research Project Foundation (TÜBAP 2016/86).

\section{References}

AL-Weher, S.M. (2008): Levels of heavy metal Cd, $\mathrm{Cu}$ and $\mathrm{Zn}$ in three fish species collected from the Northern Jordan Valley, Jordan. Jordan J. Biol. Sci., 1(1), 41-46.

Altindă̆, A. \& Yı̆̆ıT, S. (2005): Assessment of heavy metal concentrations in the food web of Lake Beyşehir, Turkey. Chemosphere, 60, 552-556.

ASTM (1985): Preparation of biological samples for inorganic chemical analysis 1, Annual book of ASTM Standards. American Society For Testing and Materials, D-19, pp. 740-747.

Çamur-Elipek, B., Arslan, N., Kirgiz, T., Öterler, B., Güher, H. \& Özkan, N. (2010): Analysis of benthic macroinvertebrates in relation to environmental variables of Lake Gala, a national park of Turkey. Turkish Journal of Fisheries and Aquatic Sciences, 10, 235-243.

Çetin, E., GüHer, H. \& Gürsoy Gaygusuz, Ç. (2016): Altinyazi baraj gölü’nde (Edirne) yaşayan balik türlerinde ağir metal birikimlerinin incelenmesi (The investigation of heavy metal accumulation of some fishes in Altinyazi Dam Lake (Edirne-Turkey)). Aquatic Sciences and Engineering, 31(1), 1-14.

Çıçek, A., Tokatli, C., Köse, E., Bașkurt, S. \& EmiroĞlu, Ö. (2017): Zinc and copper bioaccumulation levels in muscle, gill and liver tissues of an endemic fish species (Seydisuyu Stream Basin / Eskişehir / Turkey). Sigma J. Eng. Nat. Sci., 35(4), 751-755.

Di Giulio, R.T. \& Hinton, D.E. (2008): The toxicology of fishes. CRP Press, Taylor \& Francis Group, 1096 pages.

EPA (1998): Microwave assisted acid digestion of sediments, sludges, soils, and oils. Environmental Protection Agency, Method No. 3051.

EPA (2001): Determination of metals and trace elements in water and wastes by inductively coupled plasma-atomic emission spectrometry. Environmental Protection Agency, Method 200.7

FAO (1983): Compilation of legal limits for hazardous substances in fish and fishery products. Food And Agriculture Organization, FAO Fisheries Circular, C764, pp. 5-100.

Güher, H., ErdoĞan, S., Kirgiz, T. \& ÇAmur-Elipek, B. (2011): The dynamics of zooplankton in national park of lake Gala (Edirne-Turkey). Acta Zool. Bulg., 63(2), 157-168.

Güngördü, A., ERkman, A. \& KolonkayA, D. (2012): Evaluation of spatial and temporal changes in biomarker responses in the common carp (Cyprinus carpio L.) for biomonitoring the Meriç Delta, Turkey. Environ. Toxicol. Phar., 33(3), 431-439. 
Köse, E., Çıçek, A., Uysal, K., Tokatli, C., EmiroĞlu, Ö. \& Arslan, N. (2015): Heavy metal accumulations in water, sediment and some cyprinidae fish species from Porsuk Stream (Turkey). Water Environ. Res., 87(3), 195-204.

Lu, C., He, J., FAn, Q. \& Xue, H. (2011): Accumulation of heavy metals in wild commercial fish from the Baotou urban section of the Yellow River, China. Environ Earth Sci., 62, 679-696.

Newman, M.C. (2015): Fundamentals of ecotoxicology, the science of pollution, $4^{\text {th }}$ ed. CRC Press, Taylor \& Francis Group. 680 pages.

ÖZKan, N. \& ÇAmur-ElipeK, B. (2006): The dynamics of Chironomidae larvae (Diptera) and the water quality in Meric river (Edirne/Turkey). TISCIA, 35, 49-54.

Özkan, N., Moubayed-Breil, J. \& ÇAmur-Elipek, B. (2010): Ecological analysis of Chironomid larvae (Diptera, Chironomidae) in Ergene River Basin (Turkish Thrace). Turkish Journal of Fisheries and Aquatic Sciences, 10, 93-99.

Shrestha, S. \& Kazama, F. (2007): Assessment of surface water quality using multivariate statistical techniques: A case study of the Fuji River Basin; Japan. Environ. Modell. Softw., 22, 464-475.

TokAtLi, C. (2015): Assessment of the water quality in the Meriç River: As an element of the ecosystem in the Thrace Region of Turkey. Pol. J. Environ. Stud., 24(5), 2205-2211.

ToKatLI, C. (2017): Bio-ecological and statistical risk assessment of toxic metals in sediments of a worldwide important wetland: Gala Lake National Park (Turkey). Arch. Environ. Prot., 43(1), 34-47.

Tokatli, C. \& Baştatli, Y. (2016): Trace and toxic element levels in river sediments. Pol. J. Environ. Stud., 25(4), $1715-1720$.

Tokatli, C., EmiroĞlu, Ö., Çıçek, A., Köse, E., Bașkurt, S., Aksu, S., UĞurluoğlu, A., Şahin, M. \& Baştatli, Y. (2016a): Meriç Nehri Deltasi (Edirne) Baliklarinda Toksik Metallerin Biyolojik Birikimlerinin Araştirilmas (Investigation of toxic metal bioaccumulations in fishes of Meriç River Delta (Edirne)). Anadolu Unıversity Journal of Science and Technology - C Life Sciences and Biotechnology, 5(1), 1-11.

Tokatli, C., Köse, E., Arslan, N., Çiçek, A., EmiroĞlu, Ö. \& Dayioğlu, H. (2016b): Ecosystem quality assessment of an aquatic habitat in a globally important boron reserve: Emet Stream Basin (Turkey). Int. J. Environ. Pollut., 59(2/3/4), 116-141.

TS EN ISO/IEC (2017): General requirements for the competence of testing and calibration laboratories. International Standardization Organization / International Electrotechnical Commission, St. No. ISO/IEC 17025

Turkish FoOd Codex (TGK) (2008): Türk Gıda Kodeksi - Gıda Maddelerinde Belirli Bulaşanların Maksimum Seviyelerinin Belirlenmesi Hakkında Tebliğ (Communiqué on determination of maximum levels of certain contaminants in food codification of Turkish Food Codex), No: 2008/26. 